\title{
School-Based Quality Improvement Management System
}

\author{
Dian $^{1}$, Rahmat Hidayat Faturahman ${ }^{1}$, Rima Mulyawati ${ }^{1}$ \\ Manajemen Pendidikan Islam, Universitas Islam Negeri Sunan Gunung Djati Bandung, \\ Indonesia ${ }^{(1)}$ \\ DOI: $\underline{10.31004 / \text { obsesi.v6i3.1953 }}$
}

\begin{abstract}
This background aims to see the extent to which schools can be independent and empower schools through school-based management to make participatory decision-making.. The aims of this study were 1) to examine the process of implementing school-based management at $\mathrm{Al}$ Faidah Kindergarten, Cianjur; 2) learn how Al Faidah Kindergarten Cianjur in producing quality students; and 3) examine the supporting and inhibiting factors in the implementation of school-based management at the Al Faidah Kindergarten, Cianjur and how to minimize these inhibiting factors. This research method was a qualitative descriptive method. Data collection techniques in this study included 1) observation; 2) interview; and 3) documentation. It can be said that the implementation of school-based management in $\mathrm{Al}$ Faidah Kindergarten Cianjur has been implemented well. Seeing the implementation of school-based management in Al-Faidah Kindergarten, different from other schools in general that have not used school-based quality improvement management.
\end{abstract}

Keywords: quality; school-based management; kindergarten

\begin{abstract}
Abstrak
Latar Belakang ini bertujuan untuk melihat sejauh mana sekolah dapat mandiri dan memberdayakan sekolah melalui manajemen berbasis sekolah untuk melakukan pengambilan keputusan secara partisipatif. Tujuan penelitian ini 1) untuk mengkaji proses penerapan manajemen berbasis sekolah di Taman Kanak Kanak Al Faidah Cianjur; 2) mempelajari bagaimana Taman Kanak Kanak Al Faidah Cianjur dalam menghasilkan siswa yang berkualitas; dan 3) mengkaji faktor pendukung dan penghambat dalam penerapan manajemen berbasis sekolah di Taman Kanak Kanak Al Faidah Cianjur dan cara meminimalisir faktor penghambat tersebut. Metode penelitian ini adalah metode deskriptif kualitatif. Teknik pengumpulan data dalam penelitian ini meliputi 1) observasi; 2) wawancara; dan 3) dokumentasi. Analisis data kualitatif yang digunakan dalam penelitian ini 1) reduksi data, 2) penyajian atau penyajian data dan 3) penarikan kesimpulan dan verifikasi data. Dapat dikatakan bahwa penerapan manajemen berbasis sekolah di Taman Kanak Kanak Al - Faidah Cianjur sudah berjalan dengan baik. Melihat pelaksanaan manajemen berbasis sekolah di TK Al-Faidah, berbeda dengan sekolah lain pada umumnya yang belum menggunakan manajemen peningkatan kualitas berbasis sekolah.
\end{abstract}

Kata Kunci : mutu; manajemen berbasis sekolah; taman kanak-kanak

Copyright (c) 2022 Dian, et al.

$\triangle$ Corresponding author :

Email Address : rahmathidayatf668@gmail.com (Bandung, Jawa barat, Indonesia)

Received 16 September 2021, Accepted 9 January 2022, Published 16 January 2022 


\section{INTRODUCTION}

Quality is something that is an important part because basically quality always shows the superiority of the product which is always a comparison with other products. Improving quality, of course, requires effort from every institution not only as a producer of goods but also related to services. Likewise in education, quality is an important part that must be considered. Sallis (2015) revealed about Quality, namely "Quality is at the top of most agendas and improving quality is probably the most important task facing any institution. However, despite its importance, many people find quality an enigmatic concept. It is perplexing to define and often difficult to measure". In organizations, quality improvement is the most important task faced, but in reality, there are still many differences faced, especially in the concept of good quality. The effort to improve quality is an issue that continues to be discussed in education management. Improving the quality of education is a continuous effort to improve quality in meeting the expectations and demands of educational stakeholders. Of course, institutions are increasingly competitive to have good quality education. Quality improvement management is an absolute thing as an institution that manages humans to create quality humans, so it requires more extra thought than managing goods, quality in education is an evaluation of the process of educating which enhances the need to achieve and develop the talents of the customers of the process, and at the same time meets the accountability standards set by the clients who pay for the process or the outputs from the process of educating (Hoy, Jardine, \& Wood, 2005). This opinion explained that the quality of education is an evaluation of the educational process that improves the need for achievement and the process of developing the talents of students who act as customers and at the same time, it can also meet the standards of accountability set by stakeholders as clients who pay for the output of the education process so that in measuring education indicators are needed. Sallis (2005) mentioned several indicators of good quality in educational institutions, including 1) high moral values; 2 ) excellent examination results; 3 ) the support of parents, business, and the local community; 4) plentiful resources; 5) the application of the latest technology; 6) strong and purposeful leadership; 7) the care and concern for pupils and students; 8 ) a well-balanced and challenging curriculum. This opinion has explained that a quality school must have high moral values, good test results, have full support from parents, business and the local community as well as adequate resources, the latest technology that can be implemented, as well as a leadership role that has goals and concern for students and the last is a curriculum that must be balanced and relevant. Of course, in improving the quality of education, it must be seen from various sides, because until now the decline and increase in the quality of education in Indonesia has become a target that continues to be discussed.

In research by Talabudin Umkabu (Umkabu : 2009) with a research focus reference for the preparation of quality targets for MIN Malang I. From this research resulted in a reference finding for the preparation of quality targets for MIN Malang I refers to the vision, mission, and goals and targets that have been previously set. Setting these goals involves all interested elements (Madrasah Residents, Madrasah Committees, Education and Teaching Malang City and the Ministry of Religion. Malang city). Next research Dani Asmara (Asmara : 2013), in the journal published by Universitas Pendidikan Indonesia in 2013, with a research focus improving the qualifications of prospective educators. Research focused on the program improving the quality of Jamiyyah Education and Solemnity (PKKJ) in Muallimin Persis 3 teacher education with a research theme (1)development of social skills in the teacher education curriculum in Muallimin (2) vision, mission and training program (3) planning and implementation of training and (4) results of training development for social skills. The purpose of this research is to get an overview of the training program as skills development on teacher education in Muallimin Persis 3 Pameungpeuk. Research empirical study thesis compiled by Sri Marsini with focus of research efforts to improve school-based quality in SMAN 1 Sukoharjo. The research method used is descriptive qualitative with a case study design. From this research resulted in a finding efforts to maximize the supporting factors for 
the implementation of MPMBS is to improve the quality of human resources through workshops; trainings; seminar; or comparative studies, while for facilities and infrastructure, the efforts made by the school are by utilizing proper and proper maintenance of the available facilities and infrastructure (Marsini : 2013).

From a macro perspective, many factors influence the quality of education, including the curriculum factor, due to the birth of an educational policy and the variety of educational facilities as well as the presence of science and technology will be implemented and seen in the teaching and learning process. The methods, strategies, and approaches as well as evaluation of education costs and management must be carried out in a professional manner coupled with trained human resources to improve professionalism for educators and education staff. The quality of education is also related to the service process and the quality of graduates in line with good cognitive, affective and psychomotor so that students can be accepted and continue to a higher level. While the quality of service is related to activities in serving students, teachers, school committees, and all stakeholders as well as the community appropriately so that they are satisfied with the services provided by educational institutions. The quality of education can be said to be successful if it is characterized by: 1) High sense of teaching satisfaction, including high student expectations, 2) Achievement of teaching curriculum targets, 3) Excellent guidance on the spiritual, moral, social, and cultural development of teachers, 4) There are no students who have psychological problems or emotional risk 5) There is no conflict between the relationship between students and teachers or staff (Sitompul, 2006).

The initial observation of this research was on October 18th, 2021. Al-Faidah Kindergarten has been established since 2010. The school has been established for 11 years compared to the kindergartens in the vicinity. The quality offered by this school can match the quality of education with other schools. This can be seen from the results of graduates who increase every year, and some of the achievements that have been achieved by students. Seeing the closeness between the surrounding community and the school, it can be said that this school had a harmonious relationship with the community. This can be seen from the participation of the community in helping the success of all school activity programs. For example, the participation of guardians of students in helping various events held at school. However, looking at the existing facilities and infrastructure in Al-Faidah Kindergarten, it can be said that it was sufficient in meeting the standards although several things must be addressed to continue to be improved. However, this was not an obstacle for schools to implement school-based management, so that they are able to produce quality graduates.

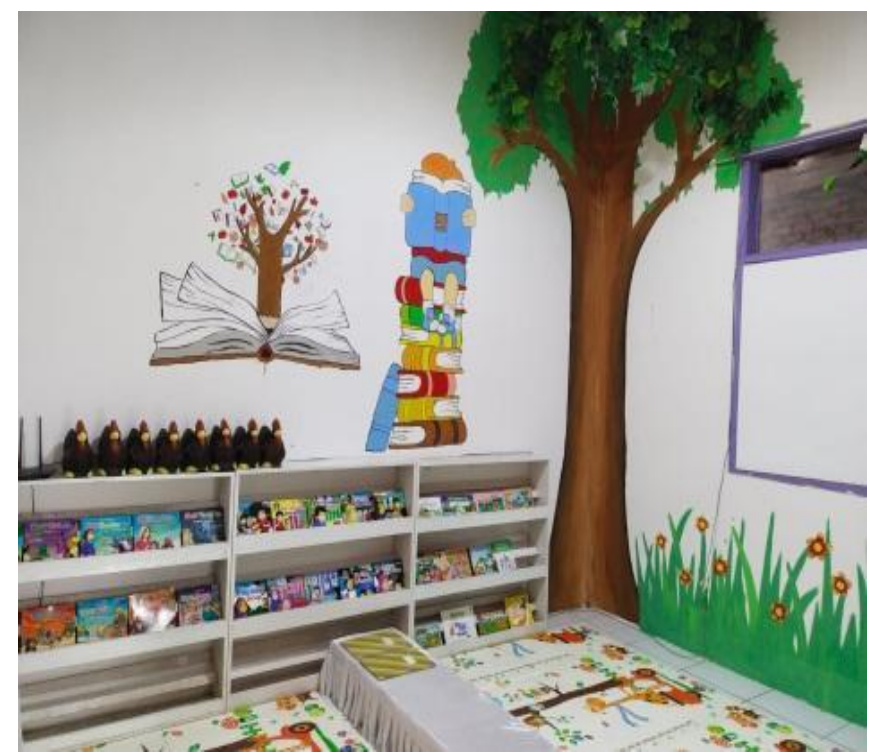

Figure 1. Library Facilities at Al-Faidah Kindergarten

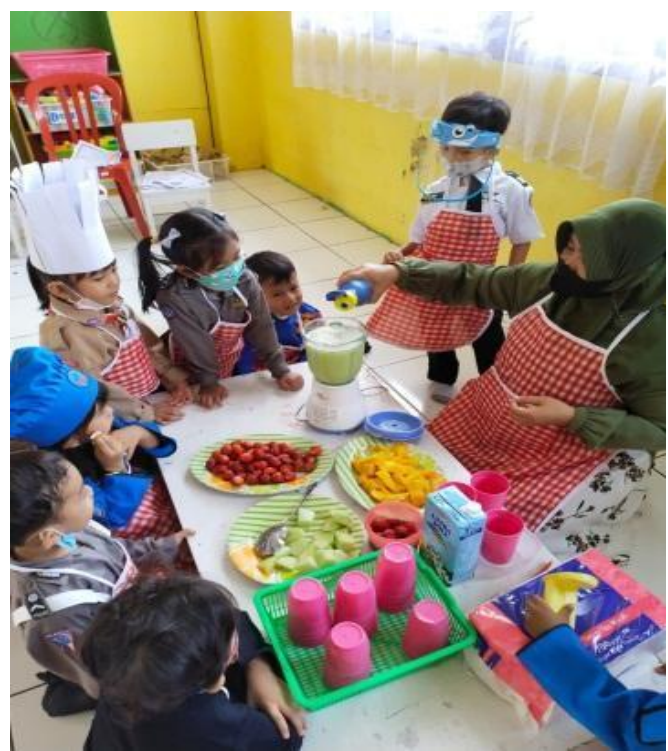

Figure 2 Cooking Class Program at AlFaidah Kindergarten 
The provisional results of this study indicated that Al-Faidah Kindergarten has been able to implement school-based management well. With the findings of student achievement, this school has also proceeded independently. Schools were also able to minimize the lack of facilities and infrastructure, for school principals, the lack of facilities and infrastructure did not dampen his intention to implement school-based management in improving the quality of education. From the problems and advantages that the researchers found, the researchers wanted to investigate further in-depth the process of implementing school-based management in improving the quality of education in Al-Faidah Kindergarten. An overview of learning facilities and cooking class program can be seen in Figures 1 and 2.

The principal as a manager, coordinator and motivator acts very democratically. The principal every morning tries to meet the teachers to discuss problems faced by teachers and students. The existing problems are discussed and solved together. Principals can empower teachers and involve them in planning activities, making important decisions, managing budget use, and developing school organization. Principals can motivate teachers to develop themselves by participating in training, upgrading, seminars, and workshops organized by the Ministry of Education and Culture as well as those organized by the Ministry of Religion.

\section{METHODOLOGY}

This study used the descriptive qualitative method. The qualitative method is used to analyze the data in the form of explanations, such as the results of observations, documentation, using two ways of thinking, namely as follows. 1) deductive thinking, namely a way of thinking that departs from general knowledge and is based on general knowledge that wants to assess a particular activity; and 2) inductive thinking, namely a way of thinking that deviates from specific facts, concrete events, then general generalizations are taken from these concrete facts (Hadi, 2011).

Data collection techniques in this study included: 1) interviews and 2) documentation. Research Instruments referred to in this study was the instrument interview. The qualitative data analysis used in this study as proposed by Sugiyono (2015) used three stages: 1) data reduction; 2) display or presentation of data, and;3) conclusion and data verification.

Interviews conducted by researchers are unstructured interviews or what are known as free interviews. Interviews conducted by researchers are interviews conducted face to face and also using telephone. Several questions were asked regarding matters related to SchoolBased Management (SBM) which was implemented in Al-Faidah Kindergarten. The next main interview was for teachers. The questions raised regarding the learning model used in carrying out the learning process are based on the School-Based concept. Document research carried out includes regulations regarding Early Childhood Education (PAUD), activity reports, photos related to the teaching and learning process and data relevant to the research objectives. The validity of the data in this study was checked by triangulation, namely: sources triangulation and method triangulation. Triangulation in principle checks the correctness of the data by matching it or comparing it with data obtained from other sources or obtained using other data collection methods.

\section{RESULT AND DISCUSSION}

In the preamble to the 1945 Constitution of the Republic of Indonesia (UUD 1945), it is stated that the Government of the State of Indonesia must be able to educate the life of the nation. To educate the nation's life, one of the most underlined ways is to improve the quality of education and its distribution in the territory of the Unitary State of the Republic of Indonesia (NKRI). The efforts made by the government in improving the quality of education were budgeting as much as $20 \%$ of the State Revenue and Expenditure Budget (APBN) and Regional Revenue and Expenditure Budget (APBD), as well as the launch of school operational assistance fund (BOS) and teacher certification to improve their welfare. Goestch and Davis as cited by Nasution (in Ibrahim \& Rusdiana, 2021) revealed that there are ten main elements of 
integrated quality management, namely 1 ) Focus on customers (customers play a major role in quality and process); 2) Obsession with quality (the organization must be obsessed with meeting or exceeding the specified); 3) Scientific Approach (the scientific approach in question is related to the decision-making process and problem-solving that is needed and used in setting benchmarks, monitoring achievements and implementing improvements); 4) Long term commitment; 5) Teamwork; 6) Continuous improvement of the system (the system must be improved continuously so that the quality of the resulting product can be increased); 7) Education and training; 8) Controlled freedom (freedom in question is problem-solving and decision making from employees to improve the sense of ownership and responsibility); 9) Unity of purpose; 10) There is employee involvement and empowerment.

School-based quality improvement management is the most important factor in the implementation of education and teaching in schools so that its success can be measured by achievement. Therefore, in carrying out leadership, it is necessary to use a system, especially in the implementation of education in schools because in it there are components related to teachers, staff, Administration (TU), parents, community, government, and students that must function optimally which are influenced by the policies and performance of the leadership. One of the challenges in improving the quality of education is to catch up in achieving achievements, especially competing in the face of global competition. This must start from the most basic, middle, and upper levels at the school level because students are expected to acquire knowledge, attitudes, and skills so that educational attainment can run optimally. Principal leadership is highly expected, especially in creating an atmosphere of openness so that the process of providing education and teaching can run optimally. Principal leadership also needs to show exemplary, especially in implementing management functions so that the achievement of goals can be achieved. One model that is considered relevant, to improve the quality of education, is through School-Based Management or Madrasah.

\section{School-Based Management}

According to Appley Rusdiana (2014) management is an activity, or the art of managing, leading, achieving, commanding, guiding, directing, and controlling. According to Subroto as cited in Ibrahim \& Rusdiana, (2021) school management is actually an application of management science in the school field. Meanwhile, according to James Jr. as cited by Sutomo (2011) that school management is the utilization of human resources in the effective administration of schools. Educational management is a process in educational institution arrangement with good potential human resources so that educational goals can be effective and efficient. In essence, the term management used in education or school has the same meaning because it is derived through the theory of administration and management in the general field.

In terms of school-based management which is an educational paradigm. According to Edmond (in Suryobroto, 2004) school-based management is a new alternative to education management that emphasizes independence and creativity. In line with that, Nurcholis stated that school-based management is an alternative form of school as a result of education decentralization. General, school-based quality improvement management can be interpreted as a management model that provides schools greater autonomy and encourages participatory decision-making that involves directly all school members (teachers, students, principals, employees, parents, and the community) to improve the quality of schools based on national education policies. Furthermore, the term school management is often juxtaposed with the term school administration. In this regard, there are three different views; first, interpreting administration more broadly than management (management is the core of administration); second, seeing management more broadly than administration (administration is the core of management); and third, who assumes that management is identic with administration. In this case, the term management is defined the same as the term administration or management, namely all joint efforts to utilize resources, both personal and material, effectively and 
efficiently in order to support the achievement of educational goals in schools optimally. The definition of management according to Hasibuan is the science and art of regulating the process of utilizing human resources and other resources effectively and efficiently to achieve certain goals. The definition of management explained to us that to achieve certain goals, we do not move alone, but need other people to work together well. Based on their main function, the terms management and administration have the same function, namely: planning, organizing, directing, coordinating, controlling, and evaluating. According to Gaffar, education management means a systematic, systemic, and comprehensive cooperation process in order to realize the goals of national education.

Objectives of School-Based Management According to Kustini Hardi (in Minarti, 2011), there are three objectives of implementing school-based management (SBM), namely: a) Developing the ability of principal together with teachers and elements of the school committee in the aspect of School-Based Management (SBM) to improve school quality, b) Developing the ability of the principal together with teachers and elements of the school committee in the implementation of active and fun learning, both at school and in the local community, c) Developing more active community participation in general school matters and elements of school committees in helping to improve school quality

According to E. Mulyasa (in Minarti, 2011), that the implementation of School-Based Management, aimed to: "... improving efficiency is obtained through, among others, the flexibility to manage community participation resources and simplifying the bureaucracy, improving the quality of education can be obtained through parental participation in schools, flexibility in school and classroom management, the enactment of a system of incentives and disensitivities, increasing equity in education, among others, obtained through increased community participation which allows the government to concentrate more on certain groups. This is possible because in some communities there is a high sense of ownership of the school". It can be understood that the objectives of School-Based Management in improving the quality of education are; "...by establishing schools to manage institutions with related parties (teachers, students, communities, parents and other institutions) so that schools and communities no longer need to wait for instructions from superiors in taking steps to advance education. They can develop an educational vision for a local situation and implement that vision independently". In creating schools that suit the needs of the local community, schools are established to meet the needs of the community and schools are also regulated by the local community. In it, community participation is very reliable in achieving the school's vision.

\section{Quality of Education in the Context of School-Based Management}

Quality can be abstract, for example in a quality way of life, an attitude of life-based on values that are considered noble and highly respected. Quality in education can be viewed in terms of its relevance to the needs of the community, whether or not graduates get a job with a high salary and the ability to overcome various life problems. The quality of education can be viewed from the benefits of education for individuals, the community, and the nation or state. Specifically, some look at the quality of education in terms of the height and breadth of knowledge achieved by someone who is studying. In addition to the above, some argued that quality education referred to various inputs, such as teaching staff, equipment, books, education costs, technology, and other inputs needed in the education process. Some were very process-oriented, with the argument that the educational process is the one that determines the quality the most so that if you have to determine quality, it is the process that must be observed and become the focus of attention. Educators must always be aware of the results obtained for students after going through a certain learning process, and the description of the results to be achieved will in turn provide motivation to seek the right inputs and processes.

In terms of the broad scope of competencies that must be achieved, the view of quality also in a broad sense includes various competencies, not only concerning the cognitive 
domain, but also affective, psychomotor, and even spiritual. Quality is not only focused on academic achievement, but also on non-academic fields, such as artistic achievement, social skills, vocational skills, social skills, such as character. Based on the practice of providing education in Indonesia so far, and the steps that have been initiated (both by the government and the community), as well as future policies, the concept of quality, is adopted in a synergistic, concurrent, and complementary manner. In Indonesia, it is known that there are excellent schools (as a "generic" name, not a school name) both those initiated by the government and those that grew on the initiative of the community, including the business world. Quality in terms of standards applied in the world of education in Indonesia as evidenced by the existence of a national curriculum that provided details of the goals to be achieved.

There are ten reasons behind the implementation of the School-Based Management policy, as follows: 1) If schools have greater autonomy, schools will be more flexible in expressing their activity or creativity in improving school quality; 2) If schools have greater flexibility in managing their resources, schools will be more agile in utilizing school resources optimally to improve school quality; 3) If the school is more aware of the strengths, weaknesses, opportunities, and threats that exist, the school can optimize the use of available resources in advancing the school; 4) If the school is more aware of the educational inputs of its institution, the school can utilize it in the educational process in accordance with the development and needs of students; 5) Decision-making by schools is more suitable to meet school needs because the school knows best what is best for the school ; 6) If the community around the school controls the use of educational resources, their use will be more effective and efficient; 7) If all school members and the community are involved in school decision making, transparency and healthy democracy will be created; 8) If the school is directly responsible for the parents of students, the community, and the government, the school will strive optimally in the implementation of achieving the planned quality of education; 9) With the support of parents of students, the community, and the government, schools can conduct healthy competition with other schools in improving the quality of education through more innovative efforts; 10) Schools can respond more quickly to rapidly changing community aspirations (Indonesian Ministry of Education, 2013). Of the ten reasons put forward by the Ministry of National Education, it can be concluded that the main objective of implementing this policy is to improve the quality of education through a more democratic model of school management. supervision activity conditions can be seen in Figure 3.

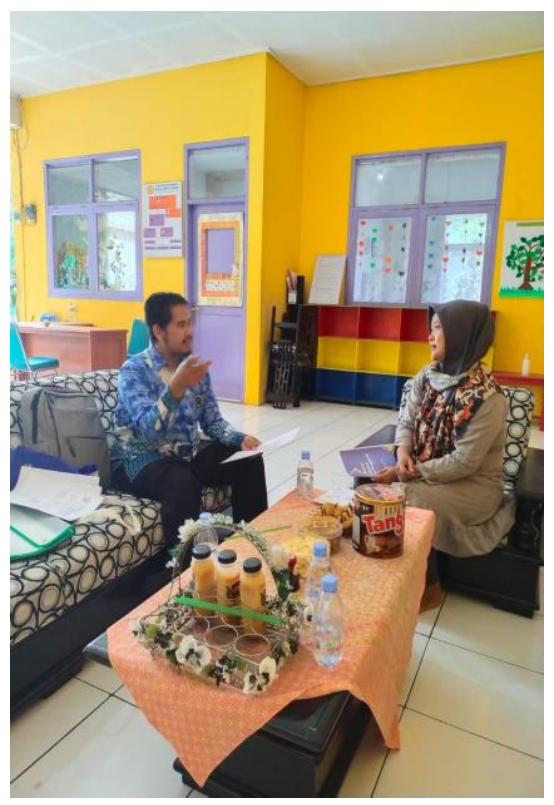

Figure 3 Supervison Activities 
The complex education management system in schools must be implemented properly so that schools can be said to be quality schools. Management components include administrative management, student management, teaching and education staff management, financial management, facilities and infrastructure management, curriculum management, and public relations management. If all of these components are implemented in an organized and coordinated dynamically, synergistically, highly loyal manner, and able to work together and be responsible for what is being done, then the school is considered successful in implementing school-based management.

In the implementation of school-based management, if seen in the field, of course, there were parts to the implementation of school-based management and the process of implementing school-based management itself, especially the implementation of school-based management in Al-Faidah Kindergarten that the researchers found. The process of implementing school-based management was in accordance with what researchers found in the field that the process consisted of input, process, and output. To measure school output, it must be seen from the achievements or achievements produced by the school. Meanwhile, school input included vision, mission, goals, objectives, organizational structure, management input, and resource input. Decision-making processes, institutional management, program management, and teaching and learning are processes that must be carried out by schools (Nurkholis, 2003).

Based on the author's analysis of the supporting theory above, Al-Faidah Kindergarten has implemented a school-based management process well. This was evidenced by what researchers found in the field through the interview, observation, and document study techniques, that the process of implementing school-based management in Al-Faidah Kindergarten is as follows: At the input stage, the principal conducts deliberation to make plans in all activities, both activities in learning or extracurricular activities. Planning, namely creating a vision, mission, and goals as well as making annual and semester programs through meetings with teachers and staff. In addition, during meetings or deliberations, the school also involves the guardians of students and the surrounding community.

The facts that researchers found with the opinion Rusdiana (2014) stated that the purpose of school-based management is to improve the quality of education. Schools can develop vision education according to local conditions and implement vision independently. With school-based management, schools do not have to wait for orders from superiors. To achieve the goals of school-based management, namely improving the quality, vision, mission of education must be adapted to local conditions, therefore Al-Faidah Kindergarten involved the community to realize the vision, mission, and educational programs and processes so that schools can adapt to community needs with the vision of Al-Faidah Kindergarten. At the process stage, the school made decisions in sorting out ideas or criticisms and whose suggestions should be applied. Once implemented, the principal will manage how it is implemented and continue to supervise the program. At this stage of the implementation process, it cannot be separated from the participation of the community in it, such as helping schools to carry out several program activities and participating in mutual cooperation in cleaning the school environment. This was in line with the explanation from the Ministry of National Education which defined school-based management as a management model that provides more autonomy to schools and encourages more participatory decision-making involving school members consisting of teachers, students, principals, employees, parents, and students. Communities directly improve the quality of schools based on national education policies.

In the context of implementing school-based management, the functions of schools that were initially run by the government were partially decentralized to schools to be run professionally. This means that certain functions cannot be fully delegated to schools, some of which were still under the authority of the central government, provincial education offices, city/regency education offices, and some were delegated to schools. The functions carried out 
by the school department in the context of school-based management included: 1) teaching and learning processes; 2) planning and evaluating school programs; 3) curriculum management; 4) management workforce; 5) equipment and equipment management; 6) financial management; 7) student services; 8) school of public relations; and 9) school climate management (Sukarti \& Wibowo, 2013).

In the implementation of school-based management, the allocation of funds to schools is greater and these resources can be used according to the needs of the school. Schools are more responsible for the maintenance, cleanliness, and use of school facilities, including the procurement of books and learning materials. This in turn will improve the quality of teaching and learning activities that take place in the classroom. Schools make plans and take their own initiatives to improve the quality of education by involving the surrounding community in the process (Rusdiana, 2014).

In the theory above, it was explained that to improve the quality of education, there must be community participation and schools must be able to be independent and be able to be responsible for school facilities. The allocation of funds must be used properly by the principal, therefore the principal must have the initiative in placing the available funds according to the needs of the school. This was in line with the opinion of Rivai and Murni, who stated that in "almost all school-based management" models, each school receives a certain amount of education budget that can be used according to its needs. The local government determines a reasonable amount of the total budget required for the implementation of educational supervision in its area, such as administrative and transportation costs, and allocates the rest to each school. The allocation for each school is determined based on a formula that takes into account the number and type of students in each school. Each school determines its own budget for the expenditures allocated to them for the payment of employees' salaries, equipment, supplies, and maintenance (Rivai \& Murni, 2017).

The equation of the research that will be compiled is with the research. The previous method was to use the same research method, namelynqualitative descriptive. While the difference between the research to be compiled with previous research is a problem of research focus. The focus of the research that will be carried out by is in terms of focus research, which is related to the concept of implementing School-Based Management that has been applied by Al-Faidah foundation at the Kindergarten level, an indication of school-based quality improvement management by describing about the implementation process in the institution. The education mainly focuses on the quality improvement process learning which includes methods, media, implementation and supervision learning. The research was carried out in 2021 with curriculum policy changes which will certainly result in research different.

The democratic and charismatic principal is clearly seen from how the principal is very open to the inspirations expressed by the teacher councils and parents of students. The principal realizes that a good organization is an organization that is clearly structured starting from the organizational structure and the main tasks of each teacher. The head of the school every morning meets first with the teachers to meet face to face and listen to the problems faced by the teachers regarding students. Any problems that arise will be discussed as soon as possible in face-to-face meetings which are held every morning. The principal is well aware that whatever becomes the school's problem must be solved together. This then becomes an important part because at this time the principal provides opportunities for teachers to help solve or find alternatives in solving problems (the principal's function is to act more as a coordinator).

The principal gives flexibility to the teachers to determine the competition to be followed. For example, creative gymnastics and dance creations created by the teacher. The teachers with their respective abilities and habits create creations according to the times. The principal only supports and continues to monitor the development of students' abilities who will take part in the competition (the principal's function as a motivator) 
In managing the learning process in the classroom, the teacher has the freedom to arrange the class structure. The class structure may be arranged in the form of the letter $U$, may be in the form of study groups, in the form of a circle, in the form of conferences, and so on. Any form is allowed as long as it can support the efficiency and effectiveness of the learning process. U-shaped classes, for example, are very good for the implementation of storytelling learning. Teachers and students can communicate better and their viewing distance is closer and not obstructed by other students. This form of group learning is very good when students are working on something by working together. They can exchange ideas and help each other more easily.

In the management of learning, teachers are given the flexibility to arrange the class structure and choose learning methods, as long as everything is done for the sake of efficiency and effectiveness of the learning process, so that learning objectives can be achieved. The storytelling method can be used to shape character, develop imagination, and foster a sense of love for God and others. In managing extracurricular learning programs, teachers can choose learning programs that can develop talent, creativity, imagination, attract interest, and develop the right brain and left brain in harmony. This good achievement is the result of the hard work of school principals, teachers, and also the role of parents in supporting school activities. Of course good results were obtained because the students had learned well from good teachers, principals, and parents.

\section{CONCLUSION}

It can be said that the implementation of school-based management in Al-Faidah Kindergarten has been implemented well. Seeing the implementation of school-based management in Al-Faidah Kindergarten, it was different from other schools in general. In addition, this school had excellent Public Relations. Management with the local community, very high community participation, between the school and the community were very close such as families helping each other, the local community was even willing to help work together to clean the school environment.

\section{ACKNOWLEDGEMENTS}

Thanks to Al-Faidah who have facilitated researchers so that this article can be published, partners who are willing to participate in research and the Obsession Journal team who have published this article so that it can be read by the public. Hopefully this article is useful both theoretically and practically.

\section{REFERENCES}

Asmara, Dani. (2013). Pengembangan Keterampilan Sosial Calon Guru: Studi Kasus pada pogram Praktek Kependidikan dan Khidmat Jamiyyah (PKKJ) di Muallimin Pesantren Persatuan Islam 3 Pameungpeuk Bandung. Tesis. Bandung: Universitas Pendidikan Indonesia

Hadi, S. (2011). Penelitian Kualitatif [Qualitative Research]. Bandung: Alfabeta.

Hoy, C., Jardine, C. B., \& Wood, M. (2005). Improving Quality in Education. London and New York: Falmer Press.

Ibrahim, T., \& Rusdiana, A. (2021). Manajemen Mutu Terpadu Total Quality Management. Bandung: Yrama Widya.

Indonesian Ministry of Education. Government Regulation No. 32 of 2013 concerning National Education Standards. , (2013). Indonesia.

Istiqomah, Laelatul. (2016). Tiga pilar Kebijakan Pemerintah dalam Pembinaan PAUD, Jurnal Ilmiah Tumbuh Kembang Anak Usia Dini, Volume 1 No. 2 https://doi.org/10.14421/iga.2016.12-05 
Marsini, Sri. (2013). Implementasi Manajemen Peningkatan Mutu Berbasis Sekolah (MPMBS) di SMA N 1 Sukoharjo, (Surakarta: jurnal UNS, Vol I No. I Hal 1 s/d 13.

Minarti, S. (2011). Manajemen sekolah: mengelola lembaga pendidikan secara mandiri. In Yogyakarta: Ar-ruzz media. Yogyakarta: Ar-ruzz media.

Moradi, S., Beidokhti, A. A., \& Fathi, K. (2016). Comparative Comparison of Implementing School-Based Management in Developed Countries in the Historical Context: From Theory to Practice. International Education Studies, 9(9), 191. https://doi.org/10.5539/ies.v9n9p191

Mujiburrahman, Ridha, \& Mahmudin. (2018). Manajemen Berbasis Sekolah berorientasi pelayanan publik : teori dan implementasinya. In Yogyakarta: Zahir Publishing, Juli 2018 (Vol. 1, Issue 1). https:// doi.org/10.24256/jpmipa.v1i1.86

Rivai, \& Murni. (2017). Education Management: Analisis Teori Dan Praktek [Education Management: Analysis of Theory and Practice]. Jakarta: Raja Grafindo Persada.

Rusdiana, H. A. (2014). Konsep Inovasi Pendidikan [Educational Innovation Concept]. Bandung: Pustaka Setia.

Sallis, E. (2015). Total Quality Management in Education. London: Kogan Page Limited. https://doi.org/10.4324/9780203417010

Sangkut. (2015). Instrumen-supervisi, Instrumen-supervisi http: / / sangkutspd.blogspot.co.id /2014/ 05 - diakses tanggal 8 Januari 2022

Sitompul, H. (2006). Pendidikan Bermutu di Sekolah. In Dalam Syafaruddin dan Mesiono (Ed.), Pendidikan Bermutu Unggul. Bandung: Cipta Pustaka Media.

Sugiyono. (2015). Metode Penelitian Kuantitatif, Kualitatif, dan Kombinasi (Mixed Methods). Bandung: Alfabeta.

Sukarti, \& Wibowo, B. U. (2013). Implementasi MBS Di Negeri Di Kabupaten Sleman [Implementation of SBM in the Country in Sleman Regency]. Jurnal Akuntabilitas Manajemen Pendidikan Universitas Negeri Yogyakarta, 1(2). https://doi.org/10.21831/amp.v1i2.2399

Suryobroto, A. S. (2004). Manajemen Pendidikan Sekolah. Jakarta: PT Rineka Cipta.

Sutomo, H. W. (2011). Pengaruh Teknologi dan Kepercayaan Atas Sistem Informasi Baru Terhadap Efektivitas Pelaporan Penggunaan Dana Bantuan Operasional Sekolah (Studi Empiris pada Sekolah Dasar Negeri dan Swasta di Kota Surabaya). FE (Akuntansi) UMY, 7(1).

Umkabu, Talabudin. (2009) Implementasi Manajemen Peningkatan Mutu Pendidikan Berbasis Madrasah (Studi Kasus di Madrasah Ibtidaiyah Negeri Malang I), Tesis, Malang: Universitas Islam Negeri Maulana Malik Ibrahim Malang 